\title{
Цвет в образе Испании
}

Е.В. Астахова

\begin{abstract}
В статье на примере Испании рассматривается участие цвета в создании образа страны как способе познания, осмысления картины мира, исторического пути народа, особенностей художественного видения. Цвет, будучи многосистемным концептом, имеет смысловую и символическую интерпретации. Он связан с другими языковыми и культурными признаками, которые охватывают универсальные категории - пространство, время, жизнь, смерть. На основе примеров из истории Испании, паремиологии, литературных произведений автор показывает культурно значимые смыслы цвета, закрепленные в сознании и коммуникации.
\end{abstract}

$\mathrm{E}$ сть страны, чей образ воспринимается сквозь призму цвета. Испания - лучший томупример. В создании образа Испании цвет активно участвует как способ познания и осмысления картины мира, фиксирует уникальную информацию об окружающей природе, своеобразии исторического пути народа, его этнических традициях, особенностях художественного видения. «...Случается час, когда солнце, как чаша расплавленного золота, разбивается, коснувшись горных вершин, и нежный свет, голубоватый, фиолетовый, алый, разливается по отрогам гор и по долине, мягко обрисовывая все очертания», - пишет испанский философ и писатель Хосе Ортега и Гассет (José Ortega y Gasset, 1883-1955) о пейзаже Центральной Кастилии, об Эскориале, одном из символов страны, и мы видим, как посредством красок удается передать «квинтэссенцию света провинций Испании» ${ }^{1}$.

Цвет - один из ключевых концептов культуры. За ним стоит мир образов, метафор, система ценностных установок, социальных отношений. Этот концепт имеет многосистемную, многоуровневую структуру, переплетенную с другими концептами и признаками. Цвет - это образ, символ, это язык, соотносящийся с пространством и временем. Он связан со стихией и природой, с такими понятиями, как счастье, горе, любовь, красота, жизнь, смерть. Этот концепт выступает в качестве социального параметра, отражает эстетические и моральные ценности, заключает в себе возможности как логического, так и чувственно-образного познания страны. Цвет как средство выражения присутствует в массовом сознании и на подсознательном уровне, в символике и мифологемах, в художественных и философских произведениях.

С давних времен у того или иного народа складывается определенная гамма любимых цветов. Формируясь на протяжении истории, цвета приобретают национальный характер, они объяснимы и традиционны, соответствуют характеру и темпераменту народа, окружающей его природе, климату и географическому положению, которые выступают как постоянные факторы, определяющие особенности развития страны. Мы знаем, что географический фактор, являясь определяющим, несет в себе множество противоречий. Принадлежность Испании к пограничной культуре, в которой уживаются Запад и Восток, не может не влиять на сознание людей. Этот противоречивый, меняющийся, подверженный противоположным влияниям мир отражается в цветовом восприятии страны.

«Географическая судьба», константные мифы и постоянная борьба между «мифологической» географией и географией «реальной» определяет и своеобразный дуализм, который всегда присутствует в Испании - сосуществование праздничного и одновременно трагического, комического и серьезного, жизни и смерти. Об этом говорит многое:

- ритуал корриды и исполнение фламенко;

- скорбные религиозные процессии и яркие, граничащие с язычеством, карнавалом праздники;

- разгул народных нравов и инквизиция (вспомним пушкинское - «с любовью набожность умильно сочетать»);

- страницы истории, в которых уживаются расцвет и упадок;

Астахова Елена Васильевна - к.и.н., доцент кафедры испанского языка МГИМО(У) МИД России.

E-mail: espanol@mgimo.ru 
- литературные герои, страдающие меланхолией и одновременно олицетворяющие радость, любовь и полноту бытия во всех проявлениях.

Это страна, по словам Федерико Гарсии Лорки, где «веками поют и пляшут», страна, где «дуэнде досуха выжимает лимоны зари», страна, «распахнутая для смерти». «В других странах смерть - это все. Она приходит, и занавес падает. В Испании иначе. В Испании он поднимается»².

При зарубежных опросах: «С каким цветом ассоциируется Испания?»- подавляющее большинство респондентов отвечает: с желтым, красным, оранжевым. Желтый, оранжевый - цвета солнца, пляжей, наслаждения жизнью, отдыхом, туризмом. Красный соответствует таким связанным с Испанией традиционным ассоциациям, как «огненные страсти», «романтический край», праздник, коррида, фламенко, в последнее время еще и «красная фурия» - сборная страны по футболу. Красный цвет также является отличительной чертой экстравертного стиля жизни, а именно испанцы не мыслят своей жизни без постоянной коммуникации, ярко проявляют экспрессии чувств - любовь, ненависть, дружбу, способность прийти на помощь, а также легковерие и максимализм. По словам Ортеги и Гассета, их интересует не действие, а порыв, подвиг, не труд, а праздник, «нескончаемый праздник», отвага стоит раньше логики, а жизнь воспринимается «страстно, напряженно, восторженно»³.

Красный и желтый (золотой) отражают главные символы Испании, цвета государственного флага Испании. Существует несколько легенд о значении этих цветов. Согласно одной из них, красный - это кровь, пролитая испанцами в сражениях за свою родину, желтый - это солнце Испании. По другой версии, цвета флага имеют непосредственное отношение к корриде (желтый песок арены и кровь быка), причем именно эта версия пользуется особой популярностью у простых жителей страны. Испанские историки полагают, что краски флага соответствуют историческим цветам фамильного герба короля Фернандо III, который отбил Севилью у арабов в 1248 г.

В национальном гимне времен правления Альфонсо XIII, короля Испании в 1886-1931 гг., деда ныне царствующего короля Хуана Карлоса I, также присутствуют золотой и пурпурный цвета. Золотой трактуется как символ власти, победы и славы, пурпурный же - как «плоть, душа, стремление к цели» (в настоящее время гимн исполняется без слов, текст пока не получил законодательного утверждения). Указанные яркие цвета представляют Испанию при первом приближении. Более глубокое познание страны, проникновение в ее историю, культуру, менталитет, стиль жизни открывают другие краски.

Цветов ведь нет, есть лишь оттенки, говорил Поль Верлен. Так и реальное понимание «картины мира» с учетом исторических трансформаций корректирует первоначальное праздничное представление.

Цвет отражает социальный и исторический опыт, определенные периоды в развитии страны и конкретные события. Средневековая символика со строгой религиозной догмой определяла черную и лиловую гамму. Ужасы инквизиции породили «черную легенду» об Испании как стране деспотизма, суеверий, жестоких нравов и диких обычаях, религиозного гнета, в которой царила зловещая и таинственная инквизиция, стране, где во славу Божию горели костры и «в великолепных автодафе сжигали злых еретиков» ${ }^{4}$.

Этот «черный» образ, созданный в конце XVI в. личным секретарем, а затем смертельным врагом Филиппа II Антонио Пересом, активно использовался геополитическими соперниками Испании - Англией, Францией, Нидерландами. «Черная легенда» о диком варварском народе, проживающем за Пиренеями, где оканчивается Европа и начинается Восток, отражала претензии к колоссальным колониальным приобретениям Испании. Любопытно, что этот образ проник на какое-то время и в русскую культуру. На Русь сведения об испанской инквизиции пришли уже в XV в. Эти известия, вероятно, вообще были первыми данными в Московии об этой далекой экзотической стране.

Новгородский архиепископ Геннадий Гонзов писал московскому митрополиту Зосиме, пересказывая ему «речи» посла императора Максимилиана I - Георгия Делятора (della Torre). Посол, проезжавший через Новгород летом-осенью 1480 г., сообщил архиепископу о борьбе Фердинанда Католика с ересями, жестоком кровавом суде, «который еретиков не терпит». Архиепископ Геннадий предлагал перенести опыт инквизиции на русскую землю ${ }^{5}$, что, к счастью, не нашло поддержки, хотя такие стереотипы, как «испанский сапог», в русском языке остались. Впоследствии в России укоренилось благоприятное, праздничное видение страны, связанное с другими красками.

Испанские историки называют романтические представления о своей стране, появившиеся в XVIIIXIX вв., «желтой легендой», которые зародились благодаря классической литературе, прежде всего французской. Именно «желтая легенда» нашла благодатную почву в России, где родилась и уже никогда не увядала мечта о романтической пленительной Испании Дон Кихота, Дон Жуана, Кармен, рыщарей плаща и шпаги. Желтый цвет легенды ассоциируется с серенадами, кастаньетами, гитарами, страстными любовниками и тому подобными мифами и стереотипами. Цвет, безусловно, в данном случае передает различные прямые эмоциональные послания («воздух лимоном и лавром пахнет», «апельсиновые рощи») и переносные - отражает категории счастья, радости, красоты, любви.

Красному цвету соответствовал период «повышенного артериального давления нации» между 1800 и 1920 гг. ${ }^{6}$ В то же самое время царствовал и черный цвет горя. Война с Наполеоном, внутриполитические распри заставили Гойю, «мастера серебристых, серых и розовых переливов английской школы, коленями и кулаками втирать в холсты черный вар» ${ }^{7}$.

В меланхоличные серые тона первоначально были окрашены размышления представителей по- 
коления 1898 г. о ситуации в стране в условиях общенационального кризиса, охватившего Испанию после поражения в войне с США и потери последних колоний. Но именно это поколение писателей, мыслителей, общественных деятелей приведет свою страну к новому, «золотому веку» в литературе, поэзии, философии.

Если говорить о недавнем прошлом - 40-летней диктатуре Франко (1939-1975), то доминировавшими цветами в Испании были черный, коричневый и серый. Черными красками пишет Федерико Гарсия Лорка гражданскую гвардию в «Романсе об испанской жандармерии» (Romance de la guardia civil española). В присутствии жандармов гаснут любимые цвета Лорки - зеленый, золотой, голубой. В этом стихотворении поэт достигает библейских высот выражения горя, безысходности, и мы видим, как цвет оказывается связан с такими языковыми признаками, как печаль, грусть, смерть. Иносказательное обозначение цвета - «игра луны и пустыни» - усиливает восприятие трагедии:

Их кони черным-черны,

и черен их шаг печатный.

На крыльях плашей чернильных

блестят восковые пятна.

Полуночны и горбаты,

несут они за плечами

песчаные смерчи страха,

клейкую мглу молчанья.

О звонкий иььганский город!

Ты флагами весь увешан.

Желтеют луна и тыква,

играет настой черешен.

И кто увидал однаждь -

забудет тебя едва ли,

город имбирньх башен,

мускуса и печали!

О мой изьганский город!

Прочь жандармерия скачет

черным туннелем молчанья,

а ть- - пожаром охвачен.

Забьть ли тебя, мой город!

В глазах у меня отныне

пусть ииут твой дальний отсвет.

Игру луньы и пустьни ${ }^{8}$.

Серые и бурые цвета находит Пикассо для своей знаменитой «Герники», символа войны и разрушения. Los grices, «серые»- так называли в народе жандармерию, полицию Франко, подавлявшую сопротивление режиму. Los rojos, «красные» несли яркую социально-историческую коннотацию: коммунисты, республиканцы, левые движения. Цвет отражался и на эстетических нормах. В те годы в силу социальных, экономических, религиозных обстоятельств люди не носили яркие одежды, это считалось вызывающим и неприличным.

После 1975 г. в стране начинается переход к демократии. Взрыв социальной активности в различных сферах общества вызывает буйство красок, что проявляется в политике, в повседневной жизни, украшении домов, магазинов, одежде, в рекламе, в кино, в живописи, в музыке. Знаменитая мовида мадриленья, социально-культурное движение начала 1980-х гг, ознаменовавшее расцвет интеллектуальной, художественной и музыкальной жизни, стали красками новой Испании, которая пробудилась от долгого сна и вновь обрела яркие цвета.

История Испании - это история ее городов, и города-символы отмечены своим цветом. Радостная зрелищная Севилья с сине-золотыми узорами арабских мозаик демонстрирует, что главное предназначение цвета заключается в красоте. Севилья воплощает андалусскую культуру, демонстрирует взаимопроникновение мусульманских и христианских традиций, которые дополняют и обогащают друг друга, оставляя впечатление праздника. Яркое солнце освещает розовую башню Ла Хиральду, нарядные площади и разноцветные постройки, множество цветов на балконах, апельсиновые деревья, при этом человек чувствует себя частью некоего цветового театрализованного действа.

Толедо - стратегический центр Реконкисты, сердце самой грозной инквизиции, одновременно центр скрещения трех культур - христианской, мусульманской и иудейской, создает напряжение застывшей «стали», громады серого камня и коричнево-серых зданий. В его облике отсутствуют яркие пятна, даже почва имеет серовато-пепельный оттенок, во всем присутствует «какая-то беспощадность» ${ }^{9}$. Неразрывно с образом Толедо связано творчество великого Эль Греко, который писал изображения города, сделав их фоном своих картин. Цвет передает духовную жизнь персонажей. Черные и белые краски с серебристыми тенями усиливают впечатление трагичности, ирреальности его работ.

Кордоба - город, сжигаемый солнцем, с медлительной жизнью, некогда столица арабского халифата, воплощение отрешенности и одиночества: «на желтой башне колокол звенит, на желтом ветре звон плывет в зенит» ${ }^{10}$. «Севилья ранит, Кордоба хоронит», - утверждал Гарсия Лорка ${ }^{11}$. Главное притяжение Кордобы - сложенная из золотистого камня Соборная мечеть, вокруг которой вращаются история страны и ассоциации зрителей.

Эскориал вместил в себя содержание целой исторической эпохи, точки наивысшего расцвета испанской империи и начало ее упадка. Трагический надлом присутствует в контрасте света и тени, в «четких очертаниях и точных пределах» ${ }^{12}$. Холодные лиловые тона прямоугольника Эскориала напоминают, что это сооружение - монастырь. Природа изолирована от человека, пейзаж и его краски можно наблюдать издалека. На примере Эскориала можно видеть связь цвета с пространством и временем, которое застыло.

Эскориал - противоположность Гранаде, последнему оплоту мавров, она воплощает искусство радоваться жизни (черта характера, так свойственная испанцам!). Гранада - это гармония цвета и красок и ее эмоциональное воздействие не знает равных. Воспоминание о сказочной столице халифов, славе Альгамбры (от арабского аль-хамра - красная), окрашивает этот город романтическим ореолом. Розовые, золотистые, кирпичные тона вместе с зеленью садов Хенералифе и белизной квартала 
Альбайсин вызывают образы, связанные с наивной картиной мира и его признаков, таких, как счастье, красота, любовь.

Совершенно другим цветом видится Барселона, предприимчивая, основательная, повернутая спиной к остальной Испании и устремленная к морю, открытая эпохе Возрождения. Сервантес остро почувствовал атмосферу Барселоны, куда попадают после долгих странствий Дон Кихот и Санчо Панса из бедной, суровой Кастилии. Они любуются на барселонской набережной морем, которое видят впервые. «Веселое море, - восклицает писатель, - ликующая земля, прозрачный воздух... Все это вносило и вливало внезапную радость в души людей» ${ }^{13}$. Претенциозный каталонский модерн XX в. с множеством украшений, узоров, причудливых красочных форм еще более обозначает отличие и независимость Барселоны.

Интересно проследить, как в испанском языке символика цвета, его эмоциональные и оценочные смыслы проявляются в паремиологии (пословицы, поговорки, загадки и т.п.). Желтый amarillo (в отличие от золотого - oro, gualda) несет в испанском языке негативные коннотации, что связано с историческим фоном, с давними временами, когда многие яды были желтого цвета. Согласно народным суевериям, живучим до сих пор, желтый цвет приносит неудачи, связан с завистью, ревностью, жадностью и подобными человеческими слабостями. Это находит отражение в пословицах и поговорках, например: amarillo color, desesperación - желтый цвет - цвет отчаяния; mucho en su hermosura fía la que de amarillo va vestida - слишком верит в свою красоту та женщина, которая носит желтые цвета; más vale ponerse una vez rojo que ciento amarillo (de ridículo) - лучше один раз покраснеть (от стыда), чем сто раз пожелтеть ( от того, что выглядишь смешным, нерешительным).

Зеленый цвет не всегда был связан с экологическим движением, а имел в народном сознании такие коннотации: ponerse verdes de envidia - позеленеть от зависти, los chistes verdes - «зеленые», т.е. скабрезные шутки, el viejo verde (un viejo asqueroso) - пожилой мужчина, заглядывающийся на молодых девушек, допускающий неприличные шутки и т.д. Если голубой и розовый в испанском языке, так же как и в русском, несут положительные эмоции, то лиловый morado - тревожный, «плохой» цвет. Сравните: se las va a ver moradas - ему небо в овчинку покажется, он узнает почем фунт лиха. El que quiere azul celeste, que le cueste - кто хочет достигнуть небес, должен потрудиться, любишь кататься, люби и саночки возить. Puro como el azul del cielo - чистейший, незапятнанный. Sentirse como las propias rosas - чувствовать себя великолепно. В то же время фразеологизм la prensa rosa «розовая пресса» означает гламурные, «глянцевые» издания.

В литературных произведениях цвет служит для изображения действительности, но талантливый мастер, выделяя тот или иной фрагмент мира для описания, наполняет его личностным смыслом и создает свою, собственную реальность, причем нередко нетрадиционный взгляд оказывается глубже реального и создает незабываемый образ. Поэзию Гарсии Лорки можно сравнить с живописью. И так же как средства художника не ограничиваются использованием красок, поэзия - это не только слова и рифмы, она сродни кисти, холсту, палитре. Концепт цвета у Лорки встраивается в образные параллели с жизнью, любовью, творчеством, ему свойственна нарочитая алогичность. Для Лорки ночь - зеленая, ветер - желтый, голос - лиловый, звуки duende черные, в пещере «золото тонет в багряном»:

Протяжны рыдания

в гулкой пешере.

(Свиниовое

тонет в багряном.)

Цьган вспоминает

дороги кочевий.

(Зуби,ь крепостей

за туманом).

А звуки и веки -

что вскрытые вены.

(Черное

тонет в багряном.)

И в золоте слез

распльваются стены.

(И золото

тонет в багряном $)^{14}$.

Перевод А. Гелескула

По теории цвета каждая эмоция фиксирует определенные краски и каждый цвет вызывает конкретные эмоции. Тем не менее для Лорки не существует схем, он использует необычные цветовые интонации для обозначения известных и традиционных предметов. Его чувства не окрашены в банальные, расхожие в употреблении тона. Примером служит известный «Сомнамбулический романс»:

Любовь моя, ивет зеленый.

Зеленого ветра всплески.

Далекий парусник в море,

далекий конь в перелеске.

Ночами, по грудв в тумане,

она у перил сидела -

серебряный иней взгляда

и зелень волос и тела ${ }^{15}$.

Живопись - особая сфера, которая использует цвет для смысловых превращений. Цветовой образ Испании тонко воспринимали русские художники, которые посещали эту страну начиная с конца XIX в., - Илья Репин (1883 г.), Василий Васнецов (1885 г.), Константин Коровин (1888г.), Александр Головин (1897 г.), Максимилиан Волошин (1901 г., 1915 г.), Борис Кустодиев (1904 г.), Александр Бенуа (1907 г.), Валентин Серов (1910г.), Игорь Грабарь (1909г.),ПетрКончаловский(1910г.), Василий Суриков (1910 г.), Василий Поленов (1911 г.), Наталья Гончарова (1916 г.) и др.

Русские живописцы, не знавшие, как правило, языка, прочувствовали Испанию через свой 
талант, через краски, через гармонию цвета. Их пребывание в Испании было недолгим, но они смогли передать в своих картинах архетип народа, свет, воздух, краски природы. Именно цвет как чувственный метод познания, как концентрат символических смыслов помог им увидеть главное. В воспоминаниях Константина Коровина, художника, для которого краски значили больше, чем форма или сюжет, цвет отражает не только и не столько пейзаж, а выступает как атрибут праздника, впечатление о народных нравах, отражение воспоминаний и внутренних переживаний, мира, движений души.

Он, в частности, писал: «В окне вагона в раннем утре голубело море. В долинах, освещенных радостным утренним солнцем, были видны сады, как бисером осыпанные мандаринами. За долинами возносились голубые плоскогорья. Была какая-то особая радость в блистании утренней природы и в смуглых красивых лицах народа... Вышел посмотреть город. Новое, незнакомое как-то особенно очаровывает душу. Мужчины в черных плащах, вверху, на отвороте подкладки красноватый плюш; женщины тоже в черном, в мантильях. Бедные люди - в толстых серых плащах... На площади я увидел что-то вроде нашего крестного хода... В серебряных облачениях, с красным на груди; идет много молодых певчих. Пение и колокольный звон напоминали Россию... Крытый двор. С потолка свисали огромные длинные фонари восьмиугольной формы. Они были покрыты шелковой материей, оранжевой, красной, желтой. За полуоткрытой стеной синела ночь, светились окна домиков с балконами....Пестрота... Шум... У женщин были высокие гребни и розы в волосах... Глубоко вырезанные платья. На плечах - длинные китайские платки в узорах золота, с большой бахромой. Цветные корсажи всех цветов, шитые золотом; широкие юбки, в оборках из кружев. Некоторые были закутаны в кружевные косынки...Мы прошли в угол и сели за столик. Я открыл свой ящик с красками, чтобы набросать этот невиданный ресторан. В нем были жгучие краски. Испания... На середину двора вышел молодой испанец. В руках у него был высокий жезл, сверху - плоский кружок, с которого спускались вниз ленты ярких цветов.

Испанец был одет в пунцовый бархат. Короткая куртка, расшитая плотным золотым узором, белая крахмальная рубашка и черный тонкий галстук, уходивший в широкий красный пояс. Сбоку рейтуз в обтяжку шли золотые пуговицы. Белые чулки и черные туфли. Из широкой шляпы видна была сзади косичка, спрятанная в зеленую сетку. «Это тореадор...» - подумал я» ${ }^{16}$.

Если Коровин - импрессионист, то для Петра Кончаловского Испания стала толчком для поворота к новому стилю в живописи. Испания изменила его палитру, разрушила схему академизма, появилась энергия цвета, новая форма - экспрессионизм с началами конструктивизма. Кончаловский писал об Испании: «Так открылся мне „секрет" реальной живописи, противоположной по своим качествам натуралистической иллюзорности. Этот „секрет" давал какую-то новую дерзость и силу, открывал новые качества живописи, совсем далекие от импрессионизма». Цвет Испании для Кончаловского - резкий, очерченный, упрощенный, контрастный - черно-белый. Испания для него - поэма черного и белого, а остальные цвета играют подчиненную роль, «их дело подчеркивать звучность двух основных». «Природа Франции и Италии всегда насыщена воздухом, прозрачностью, цвета часто тают там в какой-то дымке. В Испании, как я говорил уже, совсем напротив - цвета страшно упрощены, черный и белый господствуют над всеми другими, как будто посыпают своим пеплом все другие краски. Для меня Испания - это какая-то поэма черного и белого, так я почувствовал ее и такой, конечно, должен был изображать» ${ }^{17},-$ писал он.

Наталья Гончарова прожила полгода в Испании, в Саламанке, в 1916 г. «В Испании Гончарова открывает черный цвет, «черный не как отсутствие, а как наличность. Черный как цвет и как свет. Здесь же впервые находит свою пресловутую гончаровскую гамму: черный, белый, коричневый, рыжий. Цвета сами по себе не яркие, яркими не считающиеся, приобретают от чистоты и соседства исключительную яркость. Картина кажется написанной красным и синим, хотя явно коричневым и белым. Яркость изнутри. (В красках, как в слове, яркость, очевидно, вопрос соседства, у нас - контекста.)» ${ }^{18}$.

После Испании, ставшей для Гончаровой самым сильным «европейским» впечатлением того времени, картины художницы приобрели глубокий религиозный смысл и новые измерения. Ее цикл «Испанки» критики сравнивали со звуком трагических месс, видением величественных замков, колоколен, иконостасов. Примечательны в этой связи рассуждения о цвете Испании английского писателя Честертона, который утверждал, что «испанцам нравятся яркие краски, а черный - самый яркий из всех цветов» ${ }^{19}$.

Александр Бенуа пишет об Испании в восторженных тонах, в его оценках также присутствует дуализм впечатлений - черный и белый цвета при восхищении «от всего испанского чудесно-красочного и грандиозного сурового пейзажа».

Дважды путешествовал по Испании Максимилиан Волошин, он оставил и рисунки, и стихи, и очерки. Наглядно присутствуют языковые и культурные признаки цвета в его стихотворении «Кастаньеты» ${ }^{20}$ :

Из страны, где солниа свет

Льется с неба жгуч и ярок,

Я привез себе в подарок

Пару звонких кастаньет.

Беспокойны, говорливы,

Отбивая звонкий стих,-

Из груди сухой оливь

Сталью вырезали их.

Щедро лентами одеть

С этой южной пестротой: 
В них живет испанский зной,

В них сокрьт кусочек света...

Танеи, быстрыци, голос звонкиц̆,

Грацииозный и простой,

С этой южной, с этой тонкой

Стрекозиной красотой.

И танцьры идут в ряд,

Облитые красным светом,

И гитарь говорят

В такт трескучим кастаньетам.

Словно шелканье иикад

В жгучий полдень жарким летом.

Цвет, являясь одним из сложнейших ментальных образований, позволяет проникнуть в образ такой яркой страны, как Испания, страны неоднозначной, многослойной, чьи «обитатели знали всегда, что...черное только еще больше подчеркивает алое и золотое» ${ }^{21}$. Эти слова Че- стертона дают ключ к испанской модели мира. Через цвет мы познаем пространство языка, культуры Испании, соединяемся с основополагающими для человека категориями жизни, смерти, любви, красоты и тем самым налаживаем взаимную коммуникацию.

Astahova E.V. Color in Character of the Spain. Summary: The article deals with the analysis of the concept of color making reference to the image of Spain. The color is a complicated multi level concept connected to universal categories as space, time, life, death. It acts as a kea and way of knowledge of the history, social relations, language, traditions, mentality and character. The author cites examples of the color's symbols in poetry, paintings, paremiology and shows as a cultural sense of color is fixed in relation to the conscience and communication.

\section{Ключевые слова}

Испания, цвет, концепт, образ, символы, смысл, языковые и культурные признаки, история, паремиология, поэзия, живопись, модель мира, межкультурная коммуникация.

\section{Keywords}

Spain, color, concept, image, symbols, sense, language, culture, history, poetry painting, model of the world, intercultural communication.

\section{Примечания}

1. Ортега и Гассет Хосе. Этюды об Испании. Киев, 1994. С.127.

2. Гарсия Лорка Ф. Избранное. Поэзия, проза, театр / Пер. с исп. М.: Издательство «АСТ», 2000.

3. Ортега и Гассет Хосе. Этюды об Испании. Киев, 1994. С. 133,134,181, 211.

4. Достоевский Ф. М. Братья Карамазовы // Полн. собр. соч.: В 30 т. Л., 1976. Т.14.

5. Алексеев М. П. Очерки истории испано-русских литературных отношений XVI-XIX века // Русская культура и романский мир. Л., 1985; Никольский В.А. Петр Петрович Кончаловский. М.: Всекохудожник, 1936.

6. Ортега и Гассет Хосе. Этюды об Испании. Киев, 1994. С.184.

7. Federico Garcia Lorca. Teoría y juego del duende. Madrid, 1933.

8. Гарсия Лорка Ф. Избранное. Поэзия, проза, театр / Пер. с исп. М.: Издательство «АСТ», 2000. С.211.

9. Каптерева Т.П. Искусство Испании. Очерки. М.:Изобразительное искусство. 1989. С. 294.

10. Гарсия Лорка Ф. Избранное. Поэзия, проза, театр. / Пер. с исп. М.: Издательство «АСТ», 2000. С.97.

11. Там же.С.90.

12. Каптерева Т.П. Искусство Испании. Очерки. М.:Изобразительное искусство, 1989. С.247.

13. Сервантес Сааведра Мигель де. Хитроумный идальго Дон Кихот Ламанчский. М.; Л., 1932.Т.2. С.730.

14. Гарсия Лорка Ф. Избранное. Поэзия, проза, театр / Пер. с исп. М.: Издательство «АСТ», 2000. С.86. Перевод А. Гелескула.

15. Там же.

16. Константин Коровин вспоминает. М.: Изобразительное искусство, 1990. С. 328, 331, 332.

17. Никольский В.А. Петр Петрович Кончаловский. М.: Всекохудожник, 1936.

18. Цветаева М.И. Наталья Гончарова. (Жизнь и творчество). Сочинения в 2 т. М.: Художественная литература, 1988.

19. Gilbert K. Chesterton. El color de España y otros ensayos. Ediciones Espuela de Plata. 2007. .P. 15.

20. Волошин М.А. Кастаньеты. В книге «Испанские мотивы в русской поэзии». М.: Центр книги Рудомино, 2011. С.45,46. 